\title{
ANALISIS WACANA KRITIS BUDAYA LITERASI MELALUI APLIKASI WEBTOON BERBASIS MEDIA PEMBELAJARAN INTERAKTIF SEBAGAI UPAYA PENINGKATAN KARAKTER SISWA SEKOLAH MENENGAH
}

\author{
Amin Khudlori, S.S, M.Hum ${ }^{1)}$, Jutono Gondohanindijo, M.Kom²) \\ ${ }^{1)}$ Fakultas Bahasa dan Sastra, Universitas AKI Semarang \\ amin.khudlori@unaki.ac.id \\ ${ }^{2)}$ Fakultas Ilmu Komputer, Universitas AKI Semarang \\ Jutono. Gondohanindijo@unaki.ac.id
}

\begin{abstract}
One of the successes in high school student learning lies in the use of learning method or model. The development of technology has given great influence on the world of today's education. Learning media that are independent and technology-based become an attraction for students to improve learning motivation and to educate students to be able to learn independently. This study aims to develop the interactive learning media through webtoon applications as an effort to shape the character of high school students through literacy culture. This research also aims to foster high school students' interest in reading through smart phone technology. The subjects of this study were high school students. The research method used is the method of triangulation which includes data triangulation, triangulation between researchers and theory triangulation. Data collection techniques used in this studywere interviews, observation and documentation. The data obtained were then analyzed using descriptive qualitative analysis techniques. The results of this study are scientific publications and products in the form of interactive learning media in an effort to strengthen the character of high school students.
\end{abstract}

Keywords: Webtoon, literacy culture, character education, interactive learning method 


\section{Pendahuluan.}

\subsection{Latar Belakang.}

Di era globalisasi setiap orang dituntut untuk bisa hidup dalam derasnya arus teknologi dan informasi. Salah satu aspek yang sangat urgen agar manusia bisa survive dalam hidup adalah pendidikan. Di era globalisasi, manusia membutuhkan pendidikan agar dapat mengembangkan potensi-potensi dirinya, agar tercipta sumber daya yang berkualitas. Pendidikan dalam hal ini merupakan suatu proses agar peserta didik memiliki pengetahuan (kognitif), sikap (afektif) dan keterampilan (psikomotor) guna bekal hidup ditengahtengah masyarakat.

Salah satu ciri seorang intelektual adalah mereka yang mampu membumikan gagasannya dengan pena. Dengan kata lain, mereka merupakan tokoh intelektual yang menggerakkan massa melalui budaya literasi (bahasa). Menurut Pelligrino, seorang sosiolog, para penulis budaya literasi adalah kaum intelektual generasi ke-dua setelah sebelumnya dikuasai oleh para pengajar. Lebih lanjut lagi, budaya literasi merupakan cermin kemajuan bangsa. Para Antropolog bahasa, seperti Lucian LevyBruhl, Claude Levi-Strauss, Walter Ong, dan Jack Goody memandang literasi (bahasa) sebagai titik pangkal pembeda masyarakat primitif dari masyarakat "beradab".
Yang menjadi permasalahan adalah bagaimana cara memanfaatkan teknologi yang ada untuk menguatkan karakter para siswa sekolah menengah melalui budata literasi. Tujuan penelitian ini adalah untuk pengembangan media pembelajaran interaktif melalui aplikasi webtoon sebagai upaya pembentukan karakter siswa sekolah menengah melalui budaya literasi. Selain itu penelitian ini juga bertujuan untuk menumbuhkan minat baca siswa sekolah menengah melalui teknologi ponsel pintar. Urgensi penelitian ini didasarkan pada peraturan presiden no 87 tahun 2017 tentang pendidikan penguatan karakter (PPK) kurikulum 2013 yang berisi lima nilai yaitu religius, nasionalis, integritas, gotong royong dan mandiri.

Pengetahuan akan tumbuh dan berkembang pada saat seseorang menghadapi pengalaman baru. Seseorang akan mencoba membangun dan memodifikasi pengetahuan awal yang telah didapat untuk berusaha memecahkan masalah oleh pengalaman tersebut. UU No. 20 Tahun 2003 menegaskan bahwa pendidikan diartikan sebagai usaha sadar dan terencana untuk mewujudkan suasana belajar dan proses pembelajaran agar peserta didik secara aktif mengembangkan potensi dirinya untuk memiliki kekuatan spiritual keagamaan, pengendalian diri, kepribadian, kecerdasan, akhlak mulia, 
serta keterampilan yang diperlukan dirinya, masyarakat, bangsa dan negara.

Keberadaan komik webtoon tidak dapat dianggap remeh karena selain berusaha menunjukkan kondisi sosial suatu masyarakat, komik juga mengungkapkan gejala psikologis melalui dinamika kepribadian tokoh dalam cerita tersebut. Dinamika kepribadian yang terlihat melalui perilaku para tokoh membantu mengungkapkan makna keseluruhan cerita. Hal ini sejalan dengan pendapat Baharuddin (2017) yang menyatakan bahwa perilaku yang tercermin dari ucapan dan tindakan tokoh dapat digunakan sebagai data atau fakta empiris yang mengacu pada psikologis tokoh.

Manusia adalah makhluk yang cerdas baik secara Intelligent Quotient (IQ), Emotional Quotient (EQ) dan Social Quotient (SQ). Hal itu dapat dicapai denga sempurna jika manusia memperoleh pendidikan melalui informasi secara maksimal. Di lingkungan keluarga, anak sejak dini sudah dikondisikan untuk bersentuhan dengan media cetak, baik itu surat kabar, majalah, ataupun buku. Literasi informasi merupakan kemampuan seseorang dalam mencari, mengoleksi, mengevaluasi atau menginterpretasikan, menggunakan, dan mengkomunikasikan informasi dari berbagai sumber secara efektif. Penguasaan literasi informasi akan menjauhkan dari kebodohan, karena di saat mempunyai suatu masalah masyarakat tahu di mana harus mencari informasi pemecahan masalahnya. Rendahnya minat baca sangat berpengaruh kepada ketrampilan literasi informasi masyarakat.

Pembelajaran merupakan proses komunikasi, yaitu proses menyampaikan pesan dari sumber pesan melalui media ke penerima pesan. Secara etimologi, media berasal dari Bahasa Latin, merupakan bentuk jamak dari kata "medium" yang berarti "tengah, perantara, atau pengantar". Media memiliki peran yang sangat penting, yaitu suatu sarana atau perangkat yang berfungsi sebagai perantara atau saluran dalam suatu proses komunikasi antara komunikator dengan komunikan. Dengan adanya media pembelajaran ini guru atau pengajar dapat memaparkan materi dengan mudah serta dapat menstimulasi pemikiran peserta didik sehingga materi yang diterima peserta didik mudah dimengerti.

\subsection{Tujuan Penelitian}

Penelitian ini bertujuan untuk meningkatkan kebiasaan membaca peserta didik melalui model pembelajaran interaktif menggunakan aplikasi webtoon sebagai upaya peningkatan karakter mereka.

\subsection{Pembatasan Masalah}

Pembatasan masalah dalam penelitian ini terletak pada penggunaan salah satu model pembelajaran interaktif, yaitu penggunaan aplikasi webtoon yang 
digunakan untuk meningkatkan minat baca siswa sekolah menengah sebagai upaya peningkatan karakter mereka.

\section{Landasan Teori}

\subsection{Penelitian Terdahulu yang Berkaitan}

Pengertian literasi tidak hanya terbatas pada membaca dan menulis saja pada implementasinya, menciptakan karya dari hasil pembacaan adalah proses selanjutnya yang identik dengan transformasi literasi dalam rangka inovasi terbarukan. Literasi ini adalah adalah sebuah titik tolak dalam pembentukan sebuah peradaban manusia.

Lankshear dan Knobel menjabarkan literasi digital sebagai bentuk kemampuan untuk memahami dan menggunakan informasi dalam berbagai bentuk dan berasal dari berbagai sumber. Literasi digital tidak hanya sekedar kemampuan secara teknis untuk mengoperasikan peralatan digital secara memadai. Lebih dari itu, literasi digital mencakup beragam keterampilan kognitif yang dibutuhkan dalam memanfaatkan dan menyelesaikan pekerjaan pada bidang digital. Contoh bentuk penerapan literasi digital adalah browsing internet, bekerja dengan database, chatting dengan menggunakan media sosial.
Sung Hyuk Yoon, Soyoung Kwon dan Kun-Pyo Lee (2015) melakukan penelitian mengenai reaksi pembaca terhadap webtoon melalui smartphone mereka yang bertujuan untuk memahami perilaku penggunanya guna mengembangkan sistem rating webtoon dengan reaksi tawa penggunanya ketika mereka membaca webtoon lewat smartphone mereka. Hasil penelitiannya menemukan adanya reaksi perilaku tawa pengguna terhadap sistem rating webtoon.

Penelitian tentang penggunaan aplikasi android juga dilakukan oleh Listiarini, Bambang Mardiono, dan Adiel Yuwono (2018) yaitu tentang Perancangan Komik Berlatar Belakang Kerajaan Majapahit untuk Menggugah Minat Remaja Terhadap Warisan Budaya Indonesia yang berisikan perancangan media komik dengan harapan dapat menghapus imej kuno, membosankan serta untuk menggugah ketertarikan remaja terhadap warisan budaya Indonesia.

Hasil penelitiannya menyatakan media Komik dapat digunakan untuk menyampaikan warisan budaya secara menarik terhadap generasi muda sekaligus mengajarkan nilai luhur tokoh yang digambarkan didalamnya.

Penelitian yang lain dilakukan oleh Dian Bagus Harmoko dan Meini Sondang Sumbawati (2017) yaitu tentang Pengembangan Mobile Webtoon Pada 
Mata Kuliah Pemrograman Game Di Universitas Negeri Surabaya. Tujuan dari penelitian ini adalah untuk mendapatkan deskripsi mengenai kevalidan Mobile Webtoon serta mengetahui respon mahasiswa pada pembelajaran pemrograman game dan untuk mengukur hasil belajar mahasiswa. Hasil penelitiannya menyatakan bahwa media pembelajaran Mobile Webtoon dapat dikatakan sangat layak digunakan sebagai media pembelajaran mahasiswa.

\subsection{Media Pembelajaran Interaktif}

Penelitian dan pengembangan multimedia pembelajaran interaktif banyak dilakukan seiring dengan perkembangan teknologi. Salah satu diantaranya adalah penelitian yang dilakukan oleh Viajayani, dkk. (2013) yang bertujuan untuk menghasilkan produk media pembelajaran fisika dengan menggunakan macromedia flash 8 pada pokok bahasan suhu dan kalor. Penelitian tersebut dilakukan dengan mengacu pada model pengembangan prosedural. Penelitian sejenis juga dilakukan oleh Safitri, dkk. (2013) untuk menghasilkan media pembelajaran matematika berbasis macromedia flash pada pokok bahasan segitiga di kelas VII SMP. Media pembelajaran tersebut diujicobakan kepada para peserta didik untuk melihat efek potensialnya terhadap pemahaman konsep peserta didik.

Metode penelitian yang digunakan adalah development research yang terdiri dari tiga tahapan yaitu analisis, desain dan evaluasi. Dari hasil uji coba diperoleh bahwa efek potensial media pembelajaran menggunakan macromedia flash terhadap pemahaman konsep siswa berada dalam kategori baik. Berdasarkan hal tersebut dapat disimpulkan bahwa media pembelajaran berbasis macromedia flash pokok bahasan segitiga yang dikembangkan efektif untuk digunakan. Keuntungan yang dirasakan dari multimedia interaktif dibandingkan dengan metode pengajaran tradisional ada beberapa, salah satunya adalah memiliki potensi untuk memberikan kemajuan yang lebih kepada para peserta didik dan membantu mereka yang membutuhkan perhatian lebih.

Multimedia memiliki kekuatan untuk menghidupkan, mengkomunikasikan informasi dinamis lebih akurat daripada diagram dan dapat membantu siswa memvisualisasikan fenomena yang tidak dapat dilihat, misalnya reaksi kimia. Multimedia interaktif banyak dikembangkan dan dimanfaatkan sebagai media presentasi, game, CD interaktif dan kuis interaktif. Kuis berasal dari kata quiz yang berarti ulangan dan interaktif berkaitan adanya interaksi dua arah.

\subsection{Budaya Literasi}

Literasi informasi merupakan kemampuan seseorang dalam mencari, mengoleksi, mengevaluasi atau menginterpretasikan, menggunakan, dan mengkomunikasikan informasi dari berbagai sumber secara efektif. Penguasaan 
literasi informasi akan menjauhkan dari kebodohan, karena di saat mempunyai suatu masalah masyarakat tahu dimana harus mencari informasi pemecahan masalahnya. Rendahnya minat baca sangat berpengaruh kepada ketrampilan literasi informasi masyarakat. Sehebat apapun perpustakaan yang dimiliki, tidak bisa berbuat banyak jika masyarakatnya tidak senang membaca.

Perkembangan teknologi informasi yang sangat cepat sudah mempengaruhi berbagai bidang kehidupan dan profesi. Pengaruh ini bisa berdampak positif dan negatif pada suatu lembaga atau institusi dalam negara. Adanya perubahan sistem pada instansi maupun lembaga pendidikan tidak terkecuali bagi perpustakaan yang memiliki fungsi sebagai penyedia informasi bagi seluruh civitas akademika. Perkembangan perpustakaan era kini mulai mengarah ke perpustakaan digital, tentunya membawa dampak yang sangat besar dalam hal pelayanannya. Kini pustakawan harus dapat melayani berbagai permintaan 'baru', misalnya agar pemustaka mendapatkan akses lebih cepat ke informasi yang dibutuhkan. Dewasa ini seiring dengan perkembangannya penting untuk diperhatikan bahwa perubahan teknologi digital akan terus menuju pada suatu konsep yang disebut sebagai era konvergensi.
Konvergensi yang dimaksud di sini adalah peningkatan digitalisasi, konten tipe yang berbeda (data, audio, suara, video) diletakkan dalam suatu format yang sama dan dikirim terus menerus (progresif) melalui berbagai variasi teknologi (komputer, handphone, televisi dsb) atau diteruskan pada platform yang berbeda. Sebab, di era konvergensi itu semua telah menjadi bagian aktivitas dan kebutuhan bagi setiap siswa, serta dimulai dari pemanfaatan gadget (gawai berbentuk laptop, tablet, ipad dan smartphone). Tentunya untuk memenuhi harapan tersebut, seorang pustakawan harus bisa beradaptasi dengan perkembangan teknologi informasi

Literasi informasi adalah kemampuan untuk tahu kapan ada kebutuhan untuk informasi, untuk dapat mengidentifikasi, menemukan, mengevaluasi, dan secara efektif menggunakan informasi tersebut untuk isu atau masalah yang dihadapi (Asra, 1998), Tidak dapat dipungkiri bahwa ada kaitan antara lembaga pendidikan dan dunia intelektual. Keduanya sangat interaktif (saling mempengaruhi) dan interdependen (saling tergantung dan membutuhkan). Salah satu cara untuk membangun tradisi ilmiah di lingkungan pendidikan adalah mengoptimalkan budaya literasi di kalangan siswa.

\subsection{Webtoon}


Webtoon merupakan akronim dari website cartoon atau juga disebut sebagai world wide web + cartoon yang merupakan sebuah gambar yang memiliki cerita atau biasa disebut komik dan dipublikasikan dengan menggunakan jaringan internet. Fenomena webtoon berasal dari negara Korea. Dilihat dari gambarnya, webtoon dianggap sebagai bagian dari manhwa, seperti halnya manga yang merupakan komik khas Jepang, manhwa merupakan ciri khas komik Korea.

Webtoon merupakan sebuah komik genre Korea tersendiri yang dihasilkan dari gabungan jaringan komunikasi super cepat Korea dengan akses individu ke komputer. Jika YouTube menyediakan UCC (usercreated content) dalam bidang video, maka perusahaan internet Korea seperti Naver dan Daum menyediakan UCC di bidang manhwa sejak awal 2000.

Keberadaan komik webtoon tidak dapat dianggap remeh karena selain berusaha menunjukkan kondisi sosial suatu masyarakat, komik juga mengungkapkan gejala psikologis melalui dinamika kepribadian tokoh dalam cerita tersebut. Dinamika kepribadian yang terlihat melalui perilaku para tokoh membantu mengungkapkan makna keseluruhan cerita. Hal ini sejalan dengan pendapat Baharuddin (2017) yang menyatakan bahwa perilaku yang tercermin dari ucapan dan tindakan tokoh dapat digunakan sebagai data atau fakta empiris yang mengacu pada psikologis tokoh.

\section{Metode Penelitian}

\subsection{Waktu dan Tempat Penelitian}

Penelitian dilaksanakan pada bulan September 2019. Pelaksanaan penelitian dilalukan di Sekolah Menengah Umum Nusa Putera Semarang.

\subsection{Metodologi Penelitian}

Metode penelitian yang digunakan adalah metode triangulasi yang meliputi triangulasi data, triangulasi antar peneliti dan triangulasi teori. Objek penelitian ini adalah siswa Sekolah Menengah. Teknik pengumpulan data menggunakan teknik wawancara, observasi dan dokumentasi yang dianalisis dengan teknik analisis kualitatif deskriptif.

Berdasarkan kajian telaah pustaka dan penelitian terdahulu, maka dikembangkan bagan alir penelitian, seperti terlihat pada gambar 1. 
Survey, wawancara, observasi, FGD dengan guru dan peserta didk Siswa Sekolah Menengah tentang kebutuhan pembelajaran bahasa Inggis sesuai kemampuan dan kompetensi SiswaSekolahMenengah, hambatan dan kekurangan model pe mbebjaran independen dan karakter secara konversional

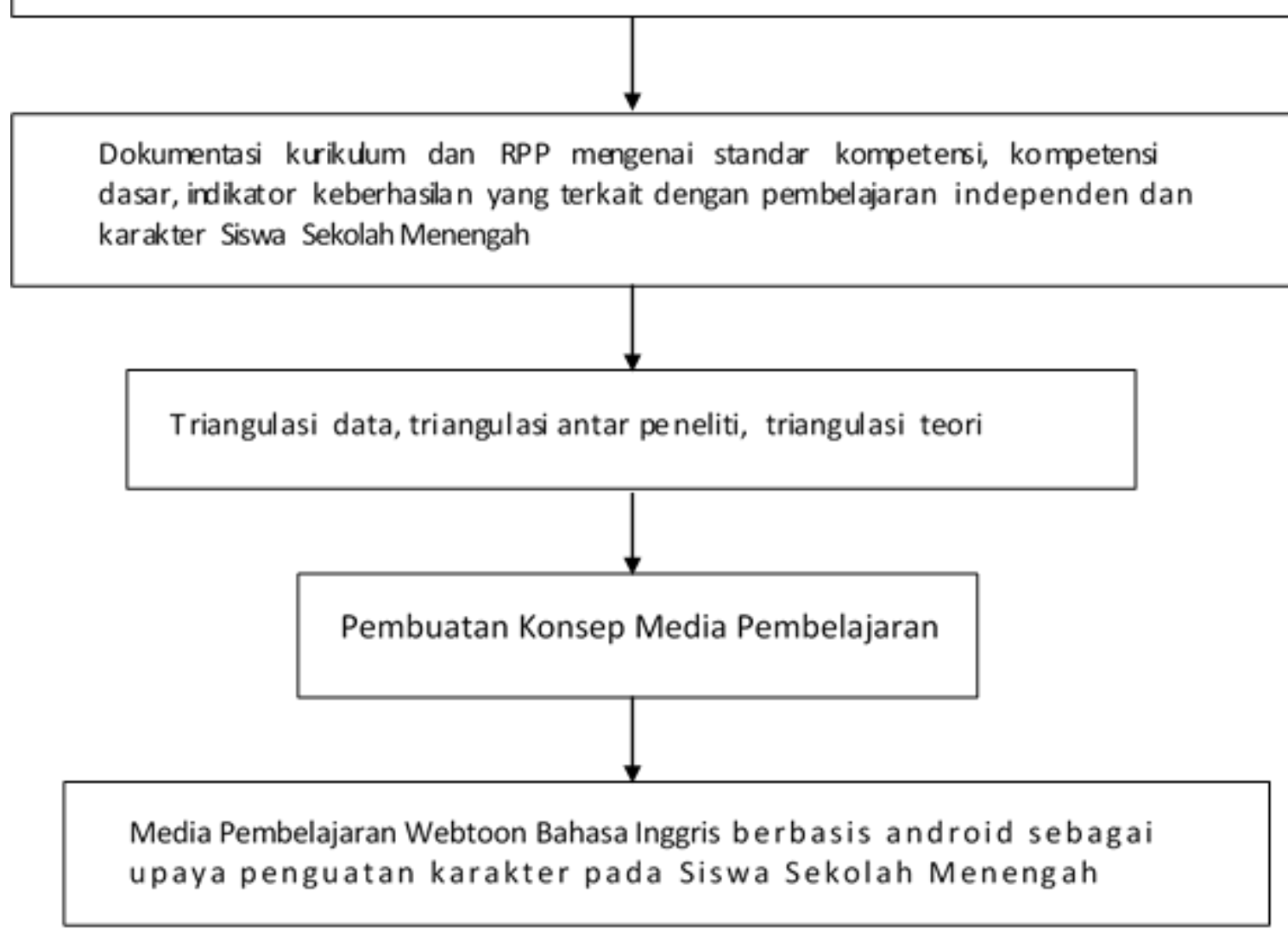

Gambar 1 Bagan alir metode penelitian

Bagan Alir Proses dan Luaran Penelitian digambarkan pada gambar 2 yang menjelaskan penahapan proses dan menunjukkan luaran dan indikator capaian penelitaian yang ditargetkan. 


\begin{tabular}{|l|l|}
\hline \multicolumn{1}{|c|}{ Tahapan } & \multicolumn{1}{c|}{ Tahun I } \\
\hline Tujuan & $\begin{array}{l}\text { Pembuatan media Webtoon bahas anggris berbas is } \\
\text { android untuk siswa Siswa Sekolah Menengah sebagai } \\
\text { upaya penguatan karakter }\end{array}$ \\
\hline Target & $\begin{array}{l}\text { Identifikasi kompetensi dasar dan standar kompetensi } \\
\text { pembelajaran bahasa Inggris untuk kecakapan } \\
\text { berbahas a dan perilaku / karakter }\end{array}$ \\
\hline Kebutuhan Data & $\begin{array}{l}\text { Data kemampuan dan kebutuhan pembelajaran peserta } \\
\text { didik Siswa Selcolah Menengah }\end{array}$ \\
\hline Metode Pengumpulan & $\begin{array}{l}\text { - In depth interview dengan guru dan peserta didik } \\
\text { Observasi lapangan terhadap peserta didik }\end{array}$ \\
\hline Analis is & $\begin{array}{l}\text { Deskriptif analitis dan analisis faktor untuk memetakan } \\
\text { atau menggambarkan kemampuan dan kebutuhan } \\
\text { pembelajaran bahasa Inggris berbasis karakter }\end{array}$ \\
\hline Outcome & $\begin{array}{l}\text { Gambaran kompetensi yang harus dimiliki mengenai } \\
\text { pembelajaran bahasa Inggris yang independen dan } \\
\text { berkarakter } \\
\text { Publikasi ilmiah dan produk Software }\end{array}$ \\
\hline
\end{tabular}

\section{Gambar 2: Bagan Alir Proses dan Luaran Penelitian}

Dalam pelaksanaan penelitian ini, terdapat langkah-langkah yang akan dilakukan, yang terbagi dalam tiga tahap, yaitu:

\section{Tahap Awal}

Tahap awal terdiri atas kegiatan pembuka. Kegiatan berupa perkenalan diri, pengenalan materi dan survey awal kepada para siswa bagaimana mereka belajar.

\section{Tahap Pelaksanaan}

Tahap pelaksanaan merupakan tahap diberikannya perlakuan berupa model pembelajaran menggunakan media pembelajaran interaktif.

\section{Tahap Akhir}

Tahap akhir dari kegiatan eksperimen berupa pemberian kuesioner. Tujuan dari pemberian kuesioner ini adalah untuk melihat pengaruh intervensi yang diberikan terhadap cara dan pola jawaban mereka.

Metode pengumpulan data yang digunakan dalam penelitian ini pengamatan aktivitas kelas yang disesuaikan dengan langkah-langkah pemecahan masalah (Santrock, 2010). Metode pengumpulan data yang digunakan dalam penelitian ini adalah dengan memberikan kuesioner. Alasan yang mendasari penggunaan kuesioner sebagai pengumpulan data, yaitu: a) menempatkan siswa dalam situasi seragam, b) memungkinkan cakupan isi yang luas, c) mengurangi unsur peluang atas pilihan pernyataan yang akan diberikan oleh penguji. Tes ini mengukur kemampuan berpikir kritis mengenai materi yang diberikan. 
Teknik analisis yang digunakan adalah analisis kualitatif deskriptif. Analisa ini dilakukan dengan bantuan alat komputer, yaitu perangkat lunak (software) Excell yang secara ilmiah dapat dipertanggungjawabkan keakuratannya.

\section{Pembahasan}

\subsection{Penyusunan Media Pembelajaran} Interaktif

Berikut rancangan interface Media pembelajaran Interaktif, yang disesuaikan dengan materi pembelajaran karakter siswa.

\section{Gambar 3. Tampilan Awal di Ponsel Android}

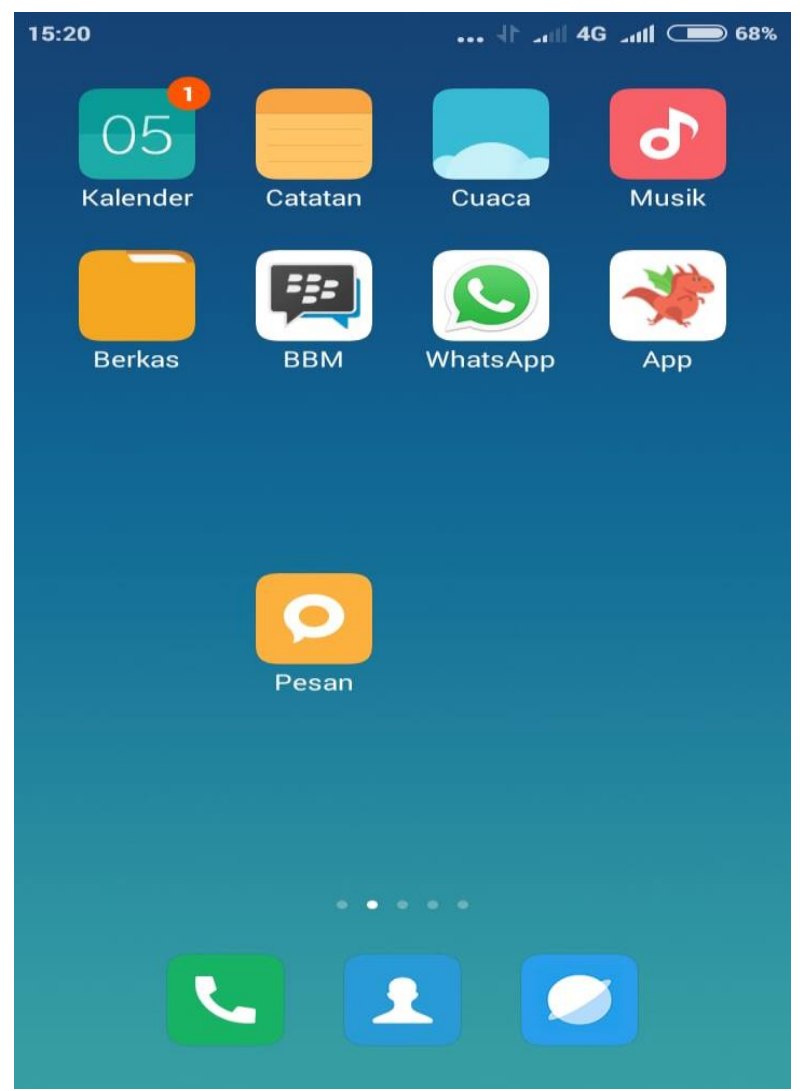




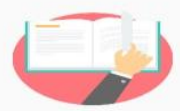

Cerita

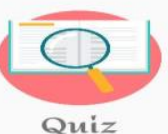

Quiz

Gambar 5. Tampilan Menu Login

masuklean nama

Masukkan Nama

MULAI

\subsection{Analisis Kualitatif Deskriptif}

Setelah disusun rencana

pembelajaran beserta medianya, maka disusunlah soal evaluasi yang berupa kuesioner untuk mengetahui bagaimana respon siswa di dalam memahami materi dan mengungkap bagaimana kemampuan berpikir kritis siswa di dalam menghadapi persoalan yang ada. Setelah didapatkan data berupa nilai hasil tes, dilakukan uji statistic sebagai berikut: 
Tabel 1. Statistik Deskriptif Nilai Kuesioner

\begin{tabular}{lr}
\hline & NILAI \\
\hline Mean & 8,102564 \\
Standard Error & 0,145999 \\
Median & 8 \\
Mode & 8 \\
Standard Deviation & 0,911762 \\
Sample Variance & 0,831309 \\
Kurtosis & 0,97682 \\
Skewness & $-0,43044$ \\
Range & 4 \\
Minimum & 6 \\
Maximum & 10 \\
Sum & 316 \\
Count & 39 \\
Largest(2) & 10 \\
Smallest(2) & 6 \\
Confidence Level $(95,0 \%)$ & 0,295559 \\
\hline
\end{tabular}

\section{Interpretasi :}

- Mean adalah Rata-rata nilai adalah 8.05 , dengan standard Error 0,14.

- Median adalah Nilai tengah yaitu 8 .

- Mode atau Modus adalah nilai yang paling sering muncul yaitu 8 .

- Standard Deviation atau Standar Deviasi adalah 0.86 .

- Sample Variance 0.75 yang juga merupakan kuadrat dari Standar Deviasi.

- Kurtosis adalah 1,13.
- Skewness adalah -0.62.

- Range nilai adalah 4 yaitu selisih dari nilai tertinggi dengan nilai terendah.

- Minimum adalah data nilai terendah yaitu 6 .

- Maximum adalah data nilai tertinggi yaitu 10 .

- Sum adalah jumlah nilai dari responden yang diteliti yaitu 306 .

- Count adalah jumlah responden yang diteliti yaitu 38 . 
- Largest(2) menunjukan nilai tertinggi nomor dua dari semua responden yang diteliti yaitu 9 .

- Smallest(2) menunjukan nilai terendah nomor dua dari semua responden yang diteliti yaitu 6 .

Berdasarkan temuan di atas, dari 39 responden didapatkan nilai rata-rata sebesar 8, yang berarti bersifat positif. Di samping itu, didapatkan siswa dengan nilai maksimum (10) 2 orang dan siswa dengan nilai terendah (6) sebanyak 2 orang, artinya model pembelajaran berbasis MPI berpengaruh terhadap kemampuan berpikir kritis siswa Sekolah Menengah Umum Nusa Putera Semarang.

\section{Kesimpulan dan Saran}

\subsection{Kesimpulan}

Pembahasan difokuskan pada penerapan aplikasi webtoon berbasis media pembelajaran interaktif sebagai media pembelajaran untuk meningkatkan budaya literasi siswa sebagai upaya peningkatan karakter mereka. Penggunaan media pembelajaran interaktif menjadikan siswa tidak hanya mempelajari materi yang ada, tetapi juga dapat meningkatkan minat baca mereka untuk menghadapi masalah dalam kehidupan nyata sehari-hari. Model pembelajaran ini dapat melatih siswa untuk menghubungkan antara apa yang mereka pelajari dengan bagaimana pengetahuan tersebut akan dimanfaatkan pada situasi baru. Model pembelajaran interaktif memberikan suatu pengalaman konkret dan pengalaman tersebut dapat memberikan makna tersendiri bagi siswa.

Melalui model pembelajaran ini dapat meningkatkan minat baca siswa sehingga membatu siswa untuk mengembangkan kemampuan berpikir, dapat memecahkan masalah, dan menjadi pembelajar otonom dan mandiri. Model pembelajaran ini mengorganisasikan siswa bekerja dalam kelompok untuk saling membantu memecahkan masalah yang kompleks. Selain itu, pembelajaran ini dapat meningkatkan kinerja siswa dalam tugas akademik, membantu siswa memahami konsep yang sulit, dan menumbuhkan kemampuan berpikir kritis siswa.

\subsection{Saran}

Berdasarkan hasil temuan penelitian, guru perlu mengembangkan diri untuk memperluas wawasan terkait penggunaan model pembelajaran yang tepat untuk mrningkatkan kemampuan peserta didik, baik secara akademis maupun non akademis. Melalui fenomena dan permasalahan nyata yang ditampilkan dalam media interaktif cukup terbukti mempenagaruhi kemampuan berpikir kritis siswa. 


\section{Daftar Pustaka}

Arends, Richard. 2008. Learning to Teach (Belajar Untuk Mengajar). Penerjemah: Helly Prajitno Soetjipto \& Sri Mulyantini Soetjipto. Yogyakarta: Pustaka Pelajar.

Baharuddin, B. (2017). Pembentukan Karakter Siswa dan Profesionalisme Guru Melalui Budaya Literasi Sekolah. El-Idare: Jurnal Manajemen Pendidikan Islam, 3(1), 21-40. Retrieved from http://jurnal.radenfatah.ac.id/index.p hp/El-idare/article/view/1283

Dian Bagus Harmoko dan Meini Sondang Sumbawati. (2017). Pengembangan Mobile Webtoon Pada Mata Kuliah Pemrograman Game Di Universitas Negeri Surabaya. Jurnal IT-EDU. Volume 02 Nomor 01 Tahun 2017, $102-109$.

Kemdikbud. 2012. UU No. 20 Tahun 2003 tentang Sisdiknas. http://www.paudni.kemdikbud.go.i d/wp-content/uploads/2012/08/UU20-2003-ttg-sisdiknas.pdf. Diakses tanggal 7/04/2019 pukul 09.17 WIB.
Listiarini, Bambang Mardiono, dan Adiel Yuwono. (2018). Perancangan Komik Berlatar Belakang Kerajaan Majapahit untuk Menggugah Minat Remaja Terhadap Warisan Budaya Indonesia.

Peraturan Menteri Pendidikan Nasional Nomor 22 Tahun 2006. 2006 http://akhmadsudrajat.files.wordpre ss.com/2009/04/permendiknas-no22-tahun-2006.pdf. Diakses tanggal 15/03/2019 pukul 21.30.

Safitri, M., Hartono, Y. dan Somakim. 2013. Pengembangan Media Pembelajaran Matematika Pokok Bahasan Segitiga Menggunakan Macromedia Flash Untuk Siswa Kelas VII SMP . Indonesian Jurnal on Computer Science Speed (IJCSS) 10 (3): 28-35.

Santrock, J. W. 2010. Psikologi Pendidikan. Alih Bahasa: Tri Wibowo. Jakarta: Kencana.

Sugiyono. 2011. Statistika Untuk Penelitian. Bandung: Penerbit Alfabeta.

SungHyuk Yoon, Soyoung Kwon dan KunPyo Lee. 2015. "Understanding User's Behavior for Developing Webtoon Rating System Based on Laugh Reaction Sensing through Smartphone". CHI 2015, Crossings, Seoul, Korea.

Trianto. 2007. Model-model Pembelajaran Inovatif Berorientasi Konstrutivistik. Jakarta: Prestasi Pustaka. 